\title{
Assessment of Vanes Effectiveness in Controlling Erosion and Deposition Zones at a River Confluence using a 2D model
}

\author{
Hydar Lafta Ali ${ }^{1}$, Badronnisa Yusuf ${ }^{1, *}$, Thamer Ahmad Mohammed ${ }^{2}$, Yasuyuki \\ Shimizu ${ }^{3}$, Mohd Shahrizal Ab Razak ${ }^{1}$, Balqis Mohamed Rehan ${ }^{1}$
}

${ }^{1}$ Department of Civil Engineering,

Universiti Putra Malaysia, 43400 Selangor, MALAYSIA

${ }^{2}$ Department of Water Resources Engineering,

University of Baghdad, Baghdad, IRAQ

${ }^{3}$ Hydraulic Research Laboratory,

Hokkaido University, Sapporo, JAPAN

*Corresponding Author

DOI: https://doi.org/10.30880/ijie.2019.11.01.024

Received 02 July 2018; Accepted 12 December 2018; Available online 15May 2019

\begin{abstract}
Controlling erosion and deposition zones that are usually forming at rivers confluences are important for improving river hydraulic efficiency. The flow in rivers confluences is highly complex, due to rapid changes associated with the river flow dynamics, sediment transport, and morphology. A two-dimensional (2D) numerical model was used to simulate the confluence between Kurau and Ara rivers, Perak, Malaysia. The numerical model has been calibrated and validated by using field data. The model was used to investigate the effectiveness of different shapes and sizes of $30^{\circ}$ obstacles/vanes in controlling erosion and deposition zones at the confluence of Kurau and Ara rivers. The simulation results show that the best performance of $30^{\circ}$ obstacles/vanes was found when a single obstacle/vane was introduced in the flow.
\end{abstract}

Keywords: Rivers confluence, erosion, deposition, investigation, $30^{\circ} \mathrm{obstacles} / \mathrm{vanes}$, simulation

\section{Introduction}

Rivers confluences are important components of the fluvial systems. They are resulted from the conjunctions between separate flowing channels and this conjunction is producing a complex hydro-morpho-dynamic environment [1]. Rapid changes in fluid motion, sediment transport, and river morphology are arising at confluences and affecting the main rivers. The main rivers attempt to accommodate the water and sediment inflow supplied from the tributaries. As confluences exist everywhere, features of drainage networks are critically vital in regulating the longitudinal distribution of flow and sediment [2]-[5]. Research on confluence dynamics is a relatively recent undertaking, and the phenomena had been studied experimentally in the laboratory, where several features were identified in order to study the mechanism of flow patterns and channel bed formation. In studying channels confluence hydraulics, the plan form angle, discharge ratio, and momentum flux ratio are considered as the major controlling factors [6]-[13]. Field investigations were performed at stream confluences in order to assess the relevance of experimental and numerical models for flow composition and morphology under natural conditions [14]-[21]. In recent years, studies on confluence have included the development of theoretical frameworks and integrate the experimental or field studies with numerical modeling [22][26]. Few studies on natural river confluences were focusing on the combination of flow and sediment transport [1], [27]. Most of the experimental and numerical studies were conducted on channel confluence confirm that there are two 
important aspects and these are erosion and deposition. Erosion is a morphological process that usually happening at the beds and outer banks of the channel confluence and known as scouring hole, while the deposition is usually happening at the inner banks (opposite to the location of erosion) and recognized as points bars or islands caused by sediment deposition. The scour hole zone is a region formed in the bed sediment erosion, resulting from the confluence of two flow cells originating from two channels, and is considered as one of the major morphological features of channel confluence. The scour hole has been associated with sediment transport caused by the increased flow turbulence and velocity intensities at the confluence [28], [3], [17]. In contrast, the deposition can be recognized clearly at the separation zone created under low pressure and flow recirculation. The separation zone at channel confluences exerts a direct influence on the flow dynamics and also morphological features [29], [30].

However, Malaysian rivers have many natural confluences and at these confluences consistent cross-section changes occurred due to sediment movement. As a result, rivers capacity is reduced, and flood levels are increased owing to sediment accumulation. In the present study, obstacles/vanes are proposed as control structures to mitigate the scouring and deposition zones in natural rivers confluence. In general, the obstacle is used to navigate both flow and bed variation. The hydraulic performance of the obstacle is mainly depending on its location, dimensions, and morphological situation [31]-[33]. For this reason, there is no specific criteria for designing the obstacle in a river system. Physical or numerical simulation is needed to optimize the design of the obstacle. However, there are some limitations on using physical models such as high cost, steady flow, and scale effect. On the other hand, numerical models are low cost and can be used efficiently for unsteady mobile bed conditions.

\section{Study Area and Data Acquisition}

The main catchment area of Bukit Merah lake is formed from the meeting of two sub-basins namely Kurau and Ara rivers. The confluence of these rivers located at the Pondok Tanjung about $7 \mathrm{~km}$ upstream Bukit Merah lake north-west of Perak state in Malaysia (Fig. 1). The rivers are started from mountain area where the averaged slope equal $12.5 \%$ while at the mid and lower reaches are characterized with low and undulating terrain with average slope around 5\%. The lower reach is more exposed to the flood due to its flat and wide floodplains [34]. The confluence of Kurau and Ara rivers have different widths and bed heights, the width of Kurau river is around $23 \mathrm{~m}$ while for Ara river it is $28 \mathrm{~m}$. The bed height of Ara river is around $0.45 \mathrm{~m}$ higher than Kurau bed height and these rivers meet at an angle of 135 degree.

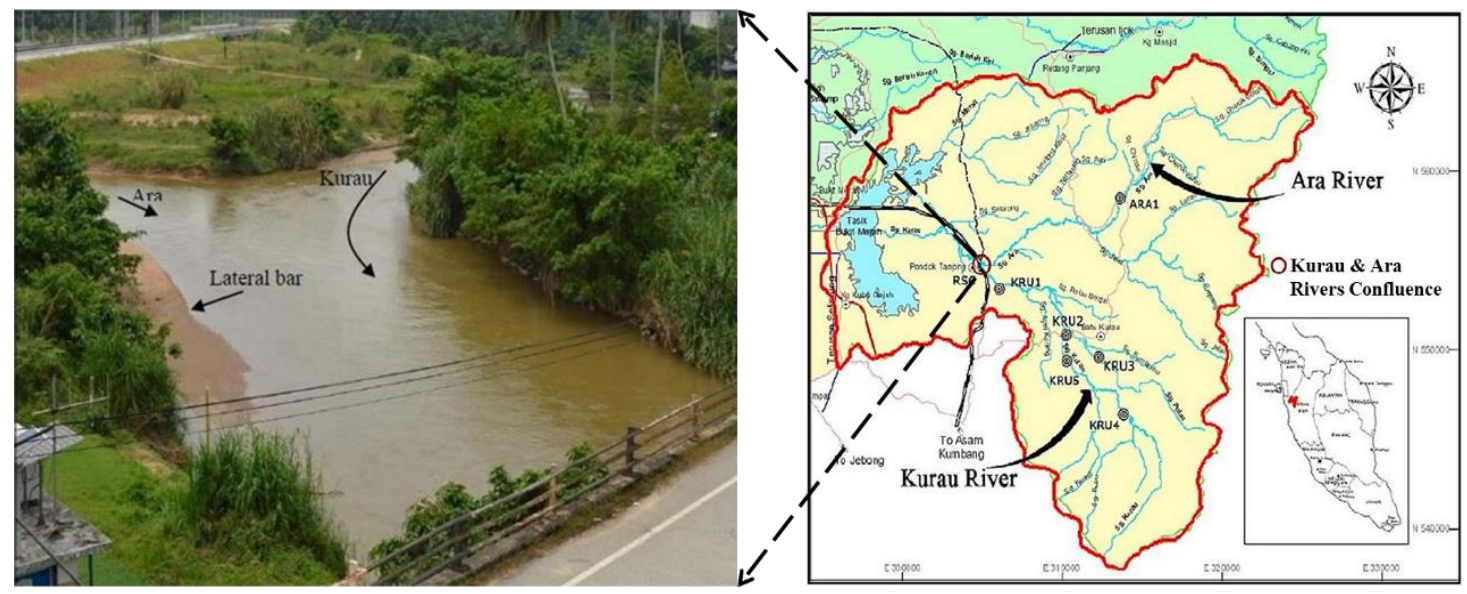

Fig. 1 - Location of Kurau and Ara rivers confluence

Hydro-Morpho dynamics data of the Kurau and Ara rivers confluence is adopted from [35]. Field works including the data of discharges, water levels, velocities, transects geometry, and sediment measurements for series of crosssections at the confluence were conducted in April and September 2012. The hydrodynamic measurements and Bathymetric surveys data were achieved by using SonTek River Surveyor device S5, Fig. 2 shows the DEM resulted from measuring many cross sections at Kurau-Ara confluence, in which the primary results from the bathymetry survey confirmed the hydro-morpho-dynamic features that were reported in the literature.

The average median particle $\left(\mathrm{d}_{50}\right)$ of bad material for Kurau and Ara rivers confluence is found to be $1.1 \mathrm{~mm}$ while for the scouring zones located near the left bank of main Kurau is found to be $1.8 \mathrm{~mm}$. One data set include discharge, velocity, water level, cross section, and bathymetry survey were measured on 09/04/2012 and it was used to build and calibrate the model, while other seven data sets were used for model validation. The discharge is changing daily since it is resulted from different rain events occurred in the catchment. 


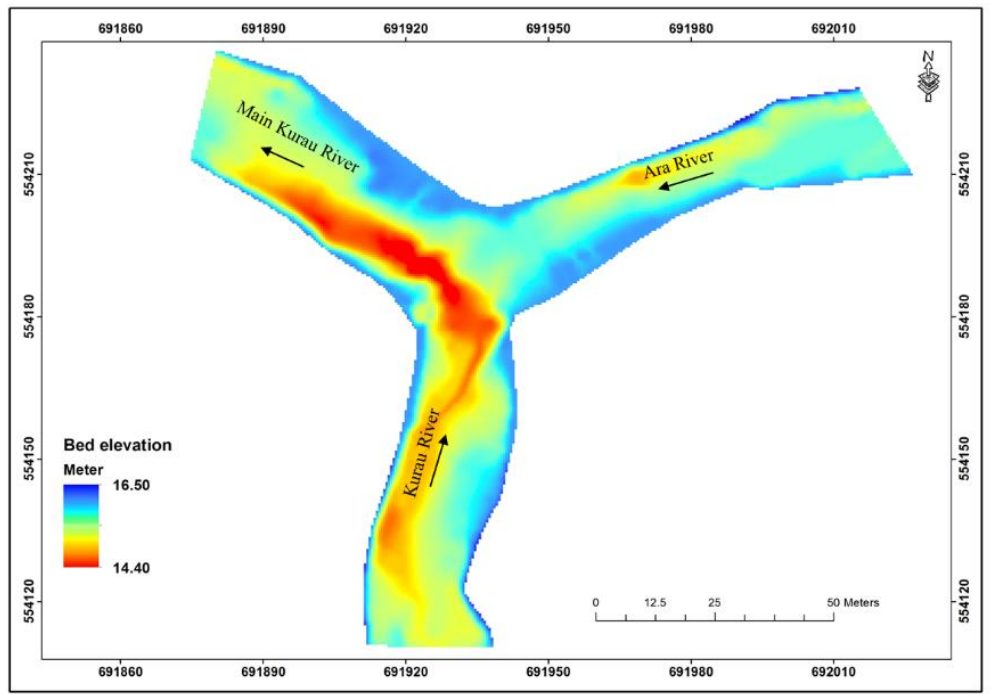

Fig. 2 - Observed bathymetry survey of the Kurau-Ara rivers confluence

\section{Numerical Modelling}

In this study, the solver Mflow_02 is used as a tool to simulate unsteady flow in rivers confluence. The original version of Mflow_02 was based on the program developed by Tomitokoro et al. [36] and it was subjected to improvements and the one that was made by iRIC [36] includes adding some functions like moving boundary model and riverbed variation calculation, etc. This make it able to calculate two-dimensional plane unsteady flow and riverbed variation by unstructured meshes of finite element method in orthogonal coordinate system (Cartesian coordinate system). The later development makes the model able to reproduce exactly the structure shape of complicated landform particularly in distributaries and confluences. For this reason, the Mflow_02 solver is used to simulate the morphodynamics of selected confluence of Kurau and Ara rivers at Perak state, Malaysia including the proposed engineering solutions of introducing obstacles/vanes at an angle of $30^{\circ}$ for controlling the scoring and deposition zones. There are two main models embedded in Mflow_02 solver and these are flow field model and riverbed variation model. These models have many submodels which can help to achieve a wide range of calculations. Fig. 3 summarized the details of solver procedures. The accuracy of the model prediction was achieved through comparison between model outputs and measured data using Four statistical methods, and these methods are Mean Absolute Deviation (MAD), Mean Square Error (MSE), Root Mean Square Error (RMSE), and Mean Absolute Percentage Error (MAPE).

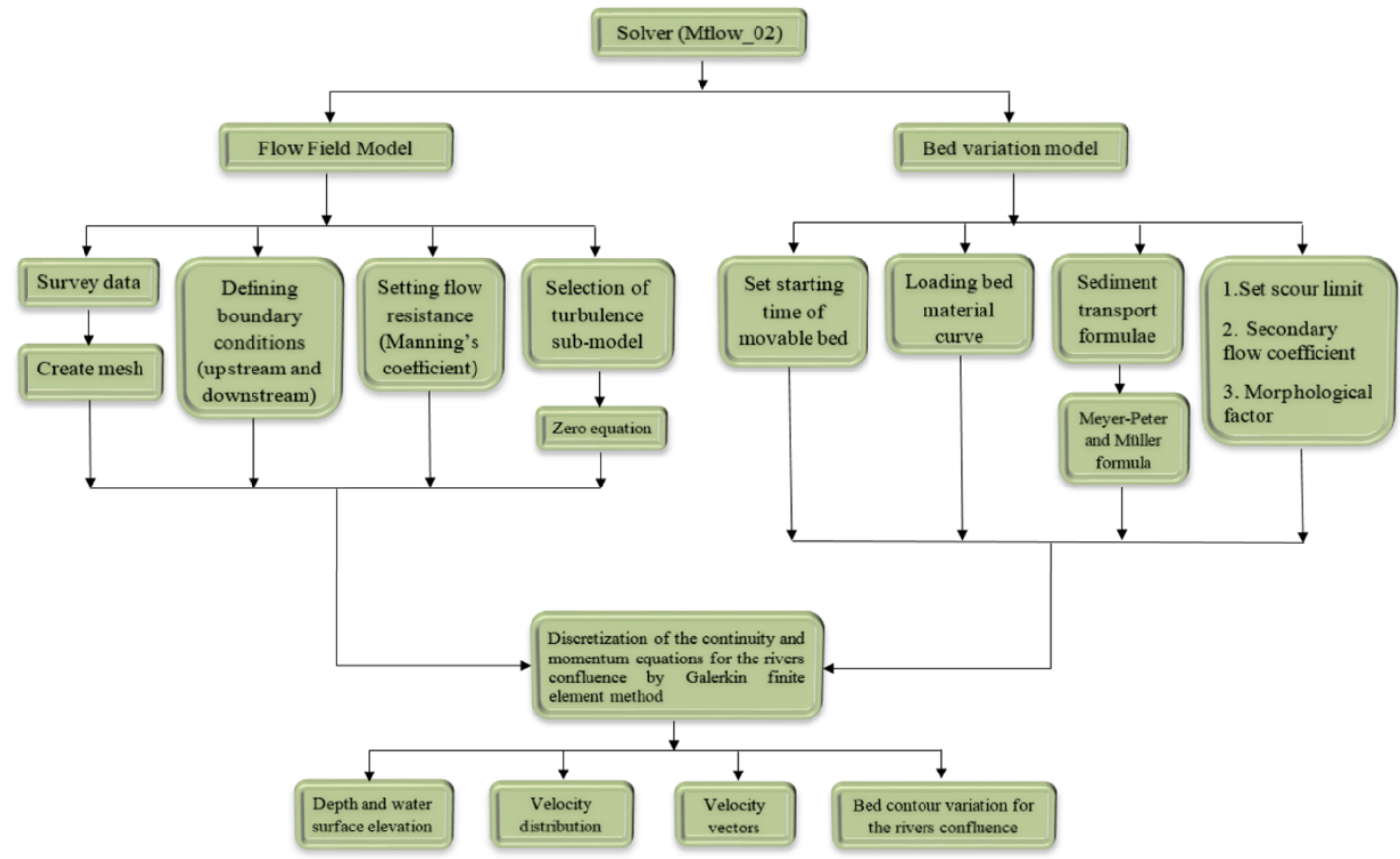

Fig. 3 - Flowchart summarizing solver procedures 


\section{Results and Discussion}

\subsection{Model Implementation and Calibration}

Mflow_02 model was used to assess the morphological changes in the river confluences. The first input data is importing a bathymetry survey. A fine unstructured grid consisted of 6136 nodes were created by drawing many lines until a good performance is found (Fig. 4). Finer grid resolution gave more accurate results, but it needs small time step. In this model, different time steps were tried until the hydrodynamic simulation run smoothly with $0.01 \mathrm{sec}$. The second input data is the curves of the grain size distribution of bed material. According to the measured data, the average median particles of the rivers are about $1.1 \mathrm{~mm}$ for the normal depth and $1.8 \mathrm{~mm}$ for the deep hole (scouring). The third input data is the flow rate at the upstream and water level at the downstream. For the turbulent model, zero equation model was adopted among the others turbulence model and then setting up the movable bed computation with starting time 800 sec after running the simulation.



Fig. 4 - Unstructured grid for Kurau and Ara rivers confluence

For sediment transport computation, Mflow_02 model uses the Ashida and Michiue [37], Meyer-Peter Müller [38], and Enguland-Hansen [39] equations to compute total bed load transport. In this simulation, the Meyer-Peter Müller equation was used. The model was calibrated with observed flow velocity, water surface elevation, and bed elevations. The model was adjusted with Manning's roughness $n=0.063[40,35]$, nodes number, time step and turbulence model until a good agreement is found between model prediction and measured data. The results of velocities magnitude for running the model 24 hours (the simulation time of the model calibration) are shown in Fig. 5, while the average values of the simulated velocities along the cross-sections in different times $(1,2,3,6,12,18,24)$ hour are shown in Figs. 6 to 11. The comparison and the errors of the measured and simulated velocities is shown in Table 1.

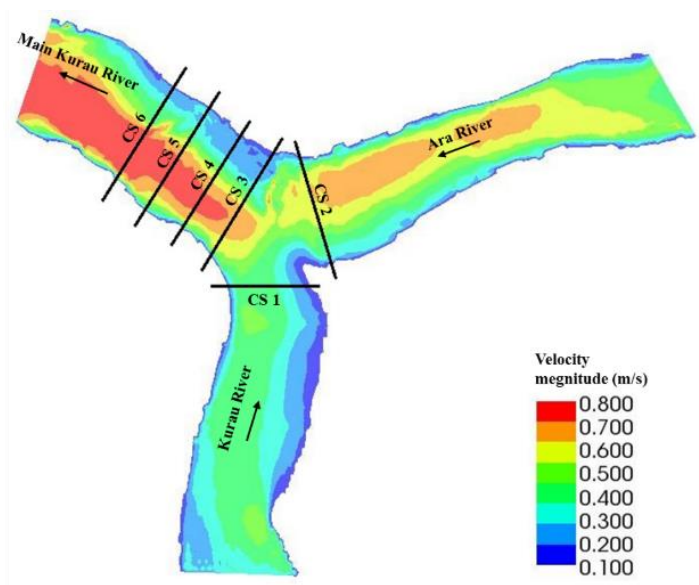

Fig. 5 - Simulation of velocity magnitude with the locations of the cross sections 


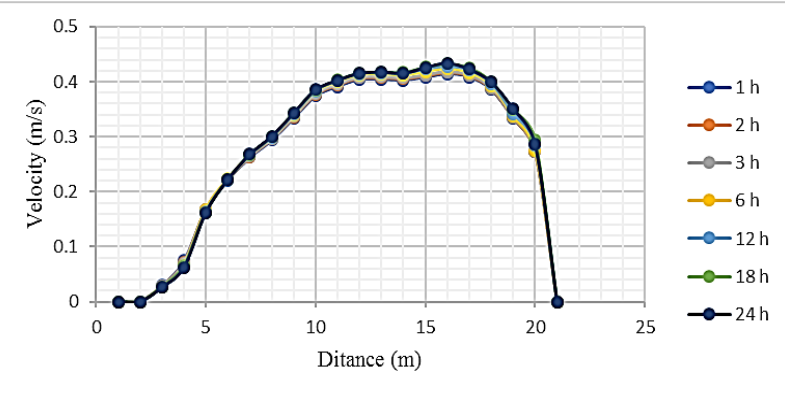

Fig. 6 - Simulated average flow velocity magnitude $(\mathrm{m} / \mathrm{s})$ within one day at cross section CS1

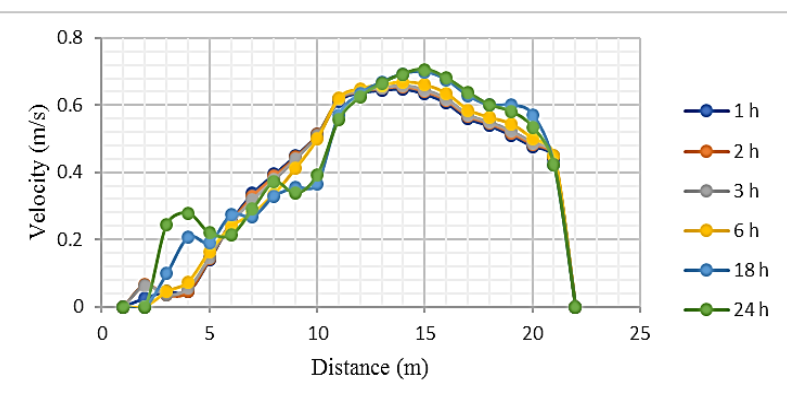

Fig. 8 - Simulated average flow velocity magnitude $(\mathrm{m} / \mathrm{s})$ within one day at cross section CS3



Fig. 10 - Simulated average flow velocity magnitude $(\mathrm{m} / \mathrm{s})$ within one day at cross section CS5

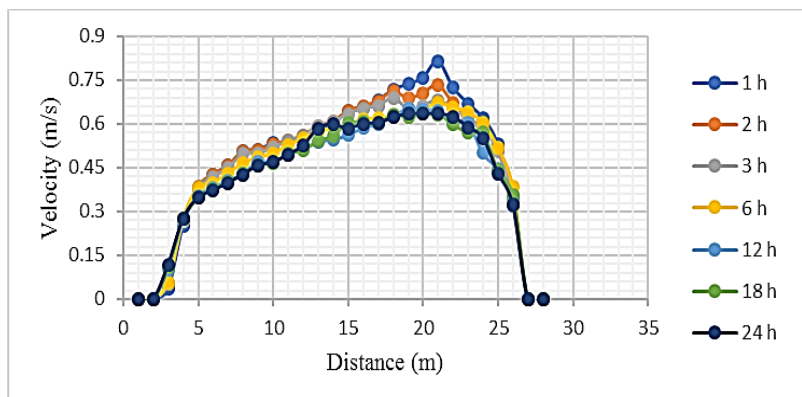

Fig. 7 - Simulated average flow velocity magnitude $(\mathrm{m} / \mathrm{s})$ within one day at cross section CS2

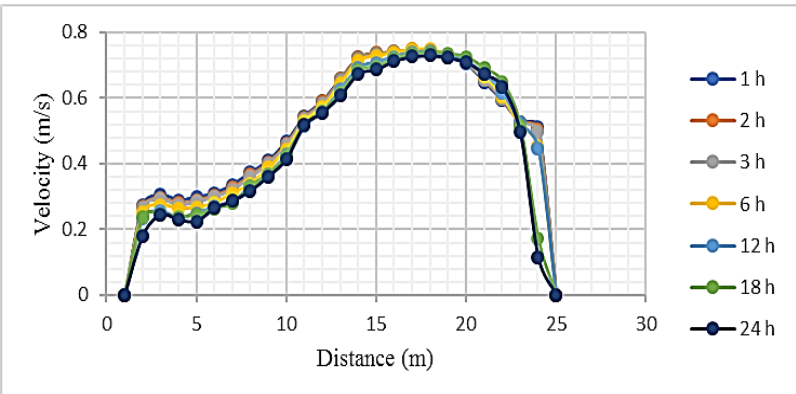

Fig. 9 - Simulated average flow velocity magnitude $(\mathrm{m} / \mathrm{s})$ within one day at cross section CS4



Fig. 11 - Simulated average flow velocity magnitude $(\mathrm{m} / \mathrm{s})$ within one day at cross section CS6

Table 1 - Comparison and Statistical indices between simulated and measured average flow velocity

\begin{tabular}{|c|c|c|c|c|c|c|c|c|}
\hline \multirow{2}{*}{$\begin{array}{l}\text { Cross- } \\
\text { Section }\end{array}$} & \multicolumn{2}{|c|}{ Average velocity $(\mathrm{m} / \mathrm{s})$} & \multirow{2}{*}{$\begin{array}{c}\text { Error } \\
\text { M-S }\end{array}$} & \multirow{2}{*}{$\begin{array}{c}\text { Absolute } \\
\text { value of } \\
\text { Errors }\end{array}$} & \multirow{2}{*}{$\begin{array}{l}\text { Square } \\
\text { of Error }\end{array}$} & \multirow{2}{*}{$\begin{array}{c}\text { Absolute } \\
\text { values of } \\
\text { errors } \\
\text { divided by } \\
\text { measured }\end{array}$} & \multirow{2}{*}{\multicolumn{2}{|c|}{$\begin{array}{l}\text { Results of } \\
\text { different } \\
\text { methods of } \\
\text { errors }\end{array}$}} \\
\hline & $\begin{array}{c}\text { Measured } \\
\text { (M) }\end{array}$ & $\begin{array}{c}\text { Simulated } \\
\text { (S) }\end{array}$ & & & & & & \\
\hline CS 1 & 0.582 & 0.536 & 0.046 & 0.046 & 0.002 & 0.079 & MAD & 0.054 \\
\hline CS 2 & 0.319 & 0.315 & 0.004 & 0.004 & 2E-05 & 0.013 & MSE & 0.004 \\
\hline CS 3 & 0.586 & 0.487 & 0.099 & 0.099 & 0.01 & 0.169 & RMSE & 0.064 \\
\hline $\mathrm{CS} 4$ & 0.572 & 0.513 & 0.059 & 0.059 & 0.003 & 0.103 & MAPE & 8.877 \\
\hline CS 5 & 0.58 & 0.56 & 0.02 & 0.02 & $4 \mathrm{E}-04$ & 0.034 & & \\
\hline CS 6 & 0.699 & 0.605 & 0.094 & 0.094 & 0.009 & 0.134 & & \\
\hline Sum. & & & & 0.322 & 0.025 & 0.533 & & \\
\hline
\end{tabular}


Four statistical indices were used to assess the prediction of Mflow_02 model and these are Mean Absolute Deviation (MAD), Mean Square Error (MSE), Root Mean Square Error (RMSE), and Mean Absolute Percentage Error (MAPE). Results from applying these methods at all cross sections showed that there is good agreement between measured and simulated average velocities as shown in Table 1.

The simulation of water surface elevation is shown in Fig. 12. The simulated and measured water surface elevations at different locations were found with minimum errors due to the boundary condition at the outlet is time-varying elevation. The values of statistical indices such as (MAD, MSE, RMSE, and MAPE) were found to be $0.024 \mathrm{~m}, 0.001 \mathrm{~m}$, $0.028 \mathrm{~m}$, and $0.144 \%$ respectively.



Fig. 12 - Simulation of water surface elevation at the confluence of Kurau and Ara Rivers

Morpho-dynamics calibration is achieved by comparing between simulated and measured bed elevations. Fig. 13 show the depths simulation with the location of four cross sections at the confluence of Kurau and Ara rivers, and these sections were used to demonstrate the difference between measured and simulated bed elevations. Figs. 14 to 17 show the comparison between simulated and measured bed elevations. The calibration process was based on the model output obtained after running the model continuously for 24 hours. The comparisons show good agreement between simulated and measured bed elevations which indicate the accuracy of model output.

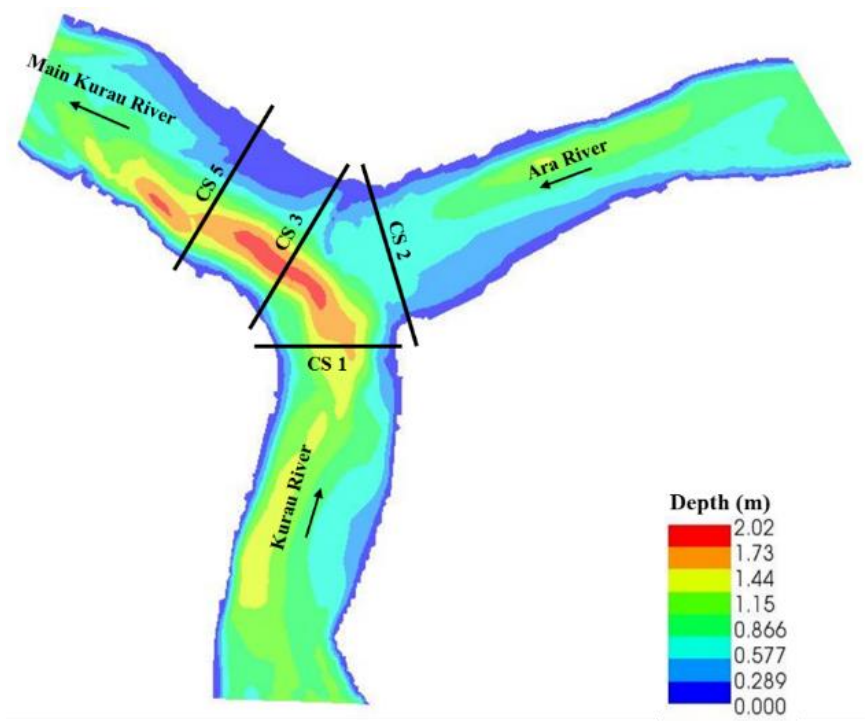

Fig. 13 - Depth simulation with the locations of measured cross-sections at the confluence of Kurau and Ara Rivers 


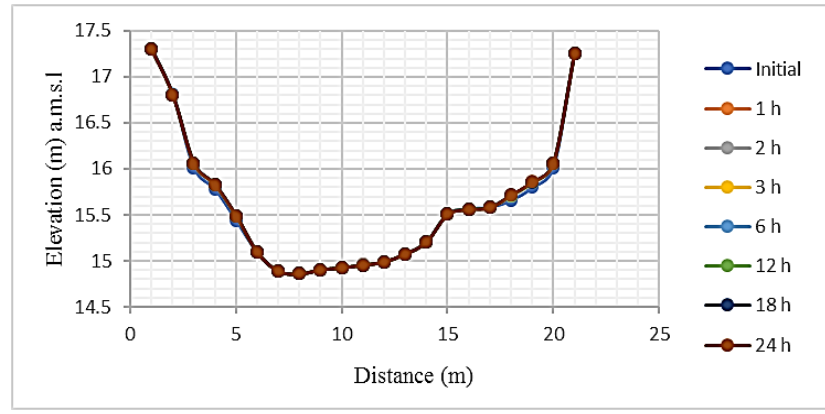

Fig. 14 - Simulated bed elevation (m) within one day at cross section CS1

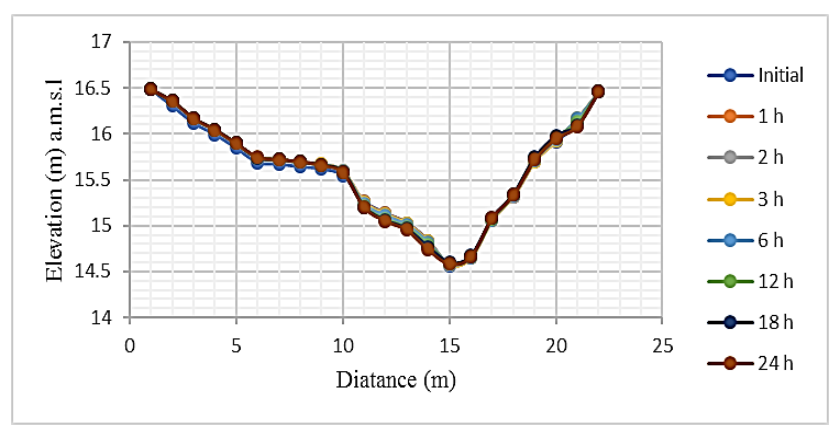

Fig. 16 - Simulated bed elevation (m) within one day at cross section CS3

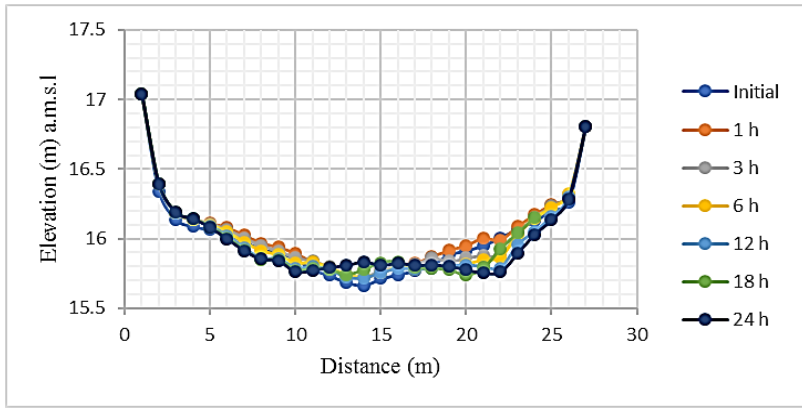

Fig. 15 - Simulated bed elevation (m) within one day at cross section CS2

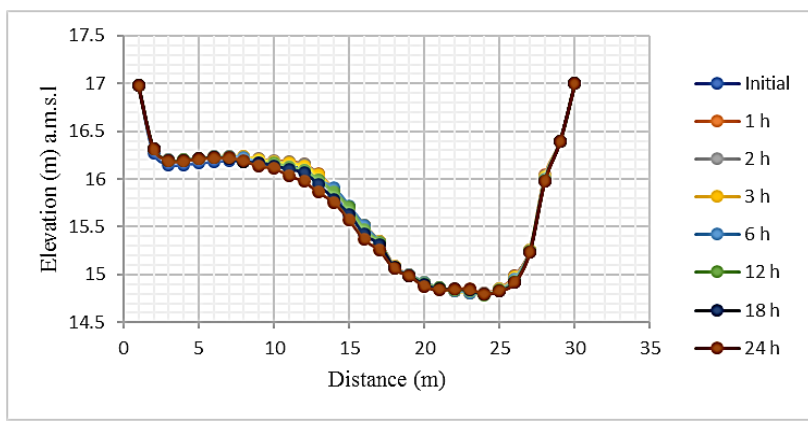

Fig. 17 - Simulated bed elevation (m) within one day at cross section CS5

\subsection{Model Validation}

The model was validated with different data sets. A comparison between simulated and measured water levels, average depths, average velocities, and bed elevations. Data for unsteady flow at upstream of Kurau and Ara rivers are shown in Table 2. The model running time was approximately 8 days for a 7 days data with 6136 nodes and $0.01 \mathrm{~s} \mathrm{time}$ step. The data of discharges is based on field measurement acquired from [35], in which high and low discharge represent different rain events occurred in the catchment.

Table 2 - Discharge of Kurau and Ara Rivers for model validation

\begin{tabular}{ccccc}
\hline \multirow{2}{*}{ No } & Time (s) & \multicolumn{2}{c}{ Discharge $\left(\mathbf{m}^{\mathbf{3}} \mathbf{s}\right)$} & $\begin{array}{c}\text { Total } \\
\text { Kurau } \\
\text { Rivcharge } \\
\left(\mathbf{m}^{3} / \mathbf{s}\right)\end{array}$ \\
\hline 1 & 0 & $\begin{array}{c}\text { Ara } \\
\text { River }\end{array}$ & \\
2 & 86400 & 8 & 7 & 9 \\
3 & 172800 & 14 & 17 & 15 \\
4 & 259200 & 15 & 28 & 43 \\
5 & 345600 & 12 & 23 & 35 \\
6 & 432000 & 10 & 15 & 25 \\
7 & 518400 & 7 & 6 & 13 \\
\hline
\end{tabular}

In order to demonstrate the accuracy of model prediction, simulation results on second and four days (with discharge of $15 \mathrm{~m}^{3} / \mathrm{s}$ and $43 \mathrm{~m}^{3} / \mathrm{s}$ ) are compared with measured. Model output showed that the water levels were simulated with high accuracy. The values of Mean Absolute Deviation (MAD), Mean Square Error (MSE), Root Mean Square Error (RMSE), and Mean Absolute Percentage Error (MAPE) were determined using the predicted and measured values. These values are found to be $0.032 \mathrm{~m}, 0.001 \mathrm{~m}, 0.034 \mathrm{~m}$, and $0.198 \%$ respectively for discharge of $15 \mathrm{~m}^{3} / \mathrm{s}$, while for discharge of $43 \mathrm{~m}^{3} / \mathrm{s}$ are equal $0.083 \mathrm{~m}, 0.008 \mathrm{~m}, 0.087 \mathrm{~m}$, and $0.484 \%$ respectively. The simulated Average flow depth fell within the observed values range, and the values of the statistical indices are found to be $0.04 \mathrm{~m}, 0.002 \mathrm{~m}, 0.044 \mathrm{~m}$, and 4.486 $\%$ associated with discharge value of $15 \mathrm{~m}^{3} / \mathrm{s}$ while for discharge value of $43 \mathrm{~m}^{3} / \mathrm{s}$ the indices are $0.075 \mathrm{~m}, 0.008 \mathrm{~m}$, $0.087 \mathrm{~m}$, and $4.707 \%$ respectively Tables 3 and 4 . 
The simulated average velocities were in agreement with the measured average velocities as shown in Table 5. Most of the simulated velocities were lower than the measured velocities and the maximum error was found with high discharge in the Kurau Rivers. The Mean Absolute Percentage Error (MAPE) was found to be 19.1\%, while at low discharge, the Mean Absolute Percentage Error (MAPE) was around to be $10 \%$. Errors refer to the uncertainty in both measured and predicted values. Papanicolaou et al., [41] reported that the typical acceptable errors in depth and velocity predictions were ranged between $25 \%$ and $35 \%$. Pinto et al., [42] suggested to accept the underprediction in velocity, due to its gave fewer errors. However, the above range of error is acceptable when it compared with other simulated results [43, 31].

Table 3 - Comparisons between water level and average flow depth for $\left(Q=15 \mathrm{~m}^{3} / \mathrm{s}\right)$

\begin{tabular}{|c|c|c|c|c|c|c|c|c|}
\hline \multirow{2}{*}{$\begin{array}{c}\text { Transect } \\
\text { name }\end{array}$} & \multicolumn{2}{|c|}{ Water level } & \multirow{2}{*}{\multicolumn{2}{|c|}{$\begin{array}{c}\text { Results of } \\
\text { different methods } \\
\text { of errors }\end{array}$}} & \multicolumn{2}{|c|}{$\begin{array}{c}\text { Average flow depth } \\
(\mathbf{m})\end{array}$} & \multirow{2}{*}{\multicolumn{2}{|c|}{$\begin{array}{c}\text { Results of } \\
\text { different methods } \\
\text { of errors }\end{array}$}} \\
\hline & Measured & Simulated & & & Measured & Simulated & & \\
\hline CS 1 & 16.44 & 16.48 & MAD & 0.032 & 1.17 & 1.12 & MAD & 0.04 \\
\hline CS 2 & 16.45 & 16.49 & MSE & 0.001 & 0.58 & 0.59 & MSE & 0.002 \\
\hline CS 3 & 16.42 & 16.45 & RMSE & 0.034 & 0.94 & 0.98 & RMSE & 0.044 \\
\hline CS 5 & 16.38 & 16.4 & MAPE & 0.198 & 0.78 & 0.84 & MAPE & 4.486 \\
\hline
\end{tabular}

Table 4 - Comparisons between water level and average flow depth for $\left(Q=43 \mathrm{~m}^{3} / \mathrm{s}\right)$

\begin{tabular}{|c|c|c|c|c|c|c|c|c|}
\hline \multirow{2}{*}{$\begin{array}{c}\text { Transect } \\
\text { name }\end{array}$} & \multicolumn{2}{|c|}{ Water level } & \multirow{2}{*}{\multicolumn{2}{|c|}{$\begin{array}{c}\text { Results of } \\
\text { different methods } \\
\text { of errors }\end{array}$}} & \multicolumn{2}{|c|}{$\begin{array}{c}\text { Average flow depth } \\
(\mathbf{m})\end{array}$} & \multirow{2}{*}{\multicolumn{2}{|c|}{$\begin{array}{c}\text { Results of } \\
\text { different methods } \\
\text { of errors }\end{array}$}} \\
\hline & Measured & Simulated & & & Measured & Simulated & & \\
\hline CS 1 & 17.29 & 17.35 & MAD & 0.083 & 1.91 & 1.92 & MAD & 0.075 \\
\hline CS 2 & 17.3 & 17.37 & MSE & 0.008 & 1.48 & 1.37 & MSE & 0.008 \\
\hline CS 3 & 17.213 & 17.34 & RMSE & 0.087 & 1.83 & 1.77 & RMSE & 0.087 \\
\hline CS 5 & 17.193 & 17.27 & MAPE & 0.484 & 1.58 & 1.7 & MAPE & 4.707 \\
\hline
\end{tabular}

Table 5 - Comparison between measured and simulated average flow velocity

\begin{tabular}{|c|c|c|c|c|c|}
\hline \multirow{2}{*}{$\begin{array}{l}\text { River } \\
\text { name }\end{array}$} & \multirow{2}{*}{$\begin{array}{c}\text { Discharge } \\
(\mathrm{m} 3 / \mathrm{s})\end{array}$} & \multicolumn{2}{|c|}{ Average velocity (m/s) } & \multirow{2}{*}{$\begin{array}{c}\text { Confluence } \\
\text { status }\end{array}$} & \multirow{2}{*}{$\begin{array}{l}\text { Momentum } \\
\text { ratio }(\mathrm{Mr})^{*}\end{array}$} \\
\hline & & Measured & Simulated & & \\
\hline Ara & 7 & 0.49 & 0.52 & \multirow{2}{*}{$15(\mathrm{~m} 3 / \mathrm{s})$} & \multirow{2}{*}{0.9} \\
\hline Kurau & 8 & 0.5 & 0.431 & & \\
\hline Ara & 28 & 0.85 & 0.752 & \multirow{2}{*}{$43(\mathrm{~m} 3 / \mathrm{s})$} & \multirow{2}{*}{2.6} \\
\hline Kurau & 15 & 0.6 & 0.44 & & \\
\hline
\end{tabular}

For morphological validation, Mflow_02 showed the model capability to simulate morphological changes such as scouring, deposition, and movement of sediment transport, which led to changes in cross section. The simulated and measured cross sections are shown in Figs. 18 to 25 . For a discharge of $15 \mathrm{~m}^{3} / \mathrm{s}$, the simulated and measured bed elevations were found in agreement particularly in cross sections 3 and 5, and less agreement were found in cross sections 1 and 2. For discharge of $43 \mathrm{~m}^{3} / \mathrm{s}$, The highest agreement between the measured and simulated cross sections with were found in cross sections 1 and 5, and least agreement were found in the cross sections 2 and 3 .

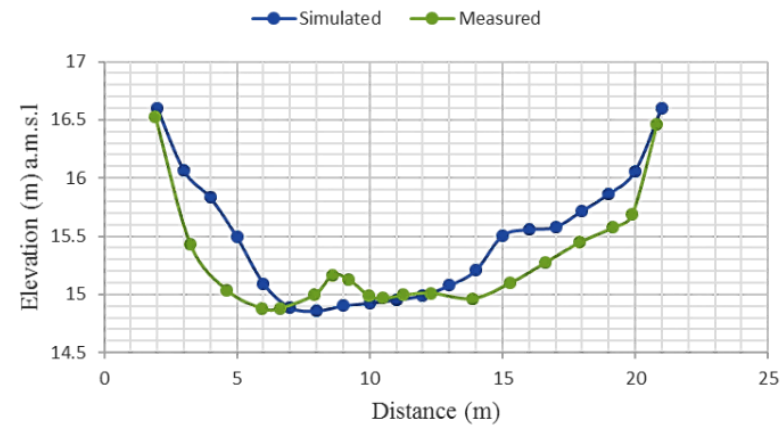

Fig. 18 - Comparison between measured and simulated bed elevation at CS1 with $\left(Q=15 \mathrm{~m}^{3} / \mathrm{s}\right)$

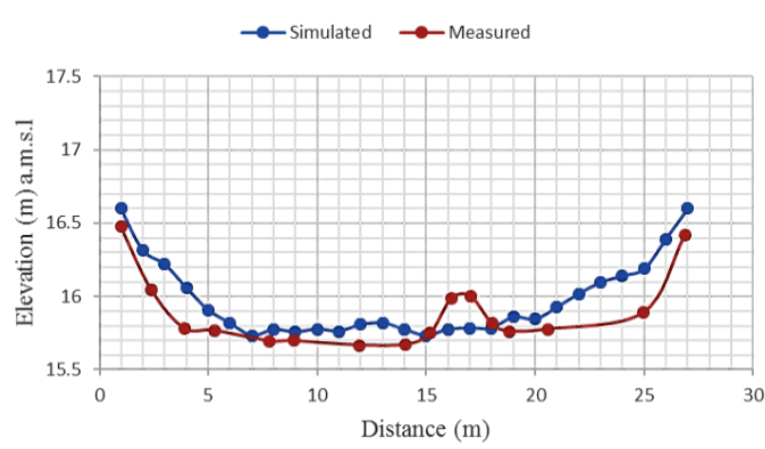

Fig. 19 - Comparison between measured and simulated bed elevation at $\mathrm{CS} 2$ with $\left(Q=15 \mathrm{~m}^{3} / \mathrm{s}\right)$ 
The errors between measured and simulated elevations of cross sections could be attributed to the spatial location of the collected data and also to a complex river reach geometry. According to Papanicolaou et al., [44], other sources of errors are computational errors from the numerical schemes used in solving the governing equations describing the studied problems and truncation errors due to discretization. In addition, some other source of errors may come from data collection. For example, the eddy viscosity models have been used in solving the governing hydrodynamic equations for turbulent flows which had some degree of empiricism in their formulations.

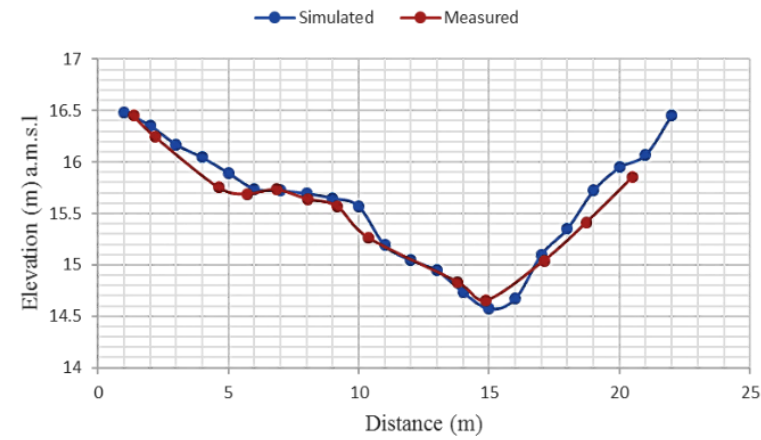

Fig. 20 - Comparison between measured and simulated bed elevation at $\mathrm{CS3}$ with $\left(\mathrm{Q}=15 \mathrm{~m}^{3} / \mathrm{s}\right)$

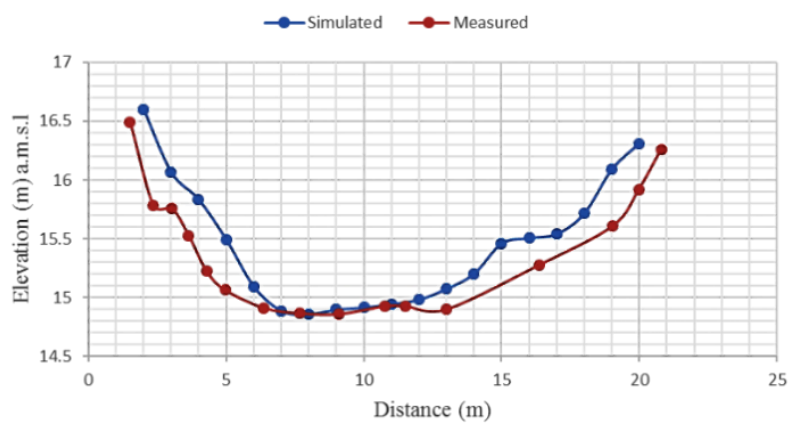

Fig. 22 - Comparison between measured and simulated bed elevation at CS1 with $\left(Q=43 \mathrm{~m}^{3} / \mathrm{s}\right)$

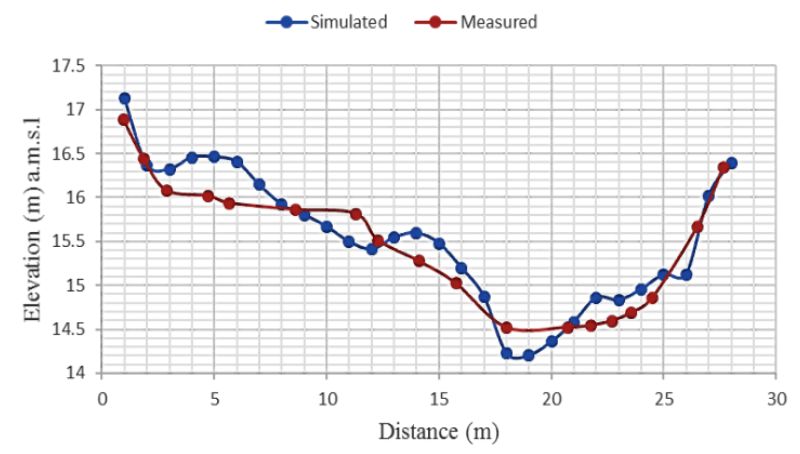

Fig. 21 - Comparison between measured and simulated bed elevation at $\operatorname{CS5}$ with $\left(Q=15 \mathrm{~m}^{3} / \mathrm{s}\right.$

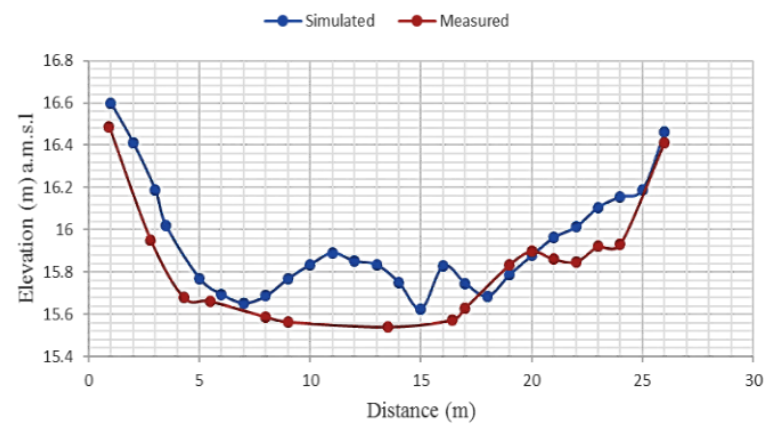

Fig. 23 - Comparison between measured and simulated bed elevation at $\mathrm{CS} 2$ with $\left(Q=43 \mathrm{~m}^{3} / \mathrm{s}\right)$
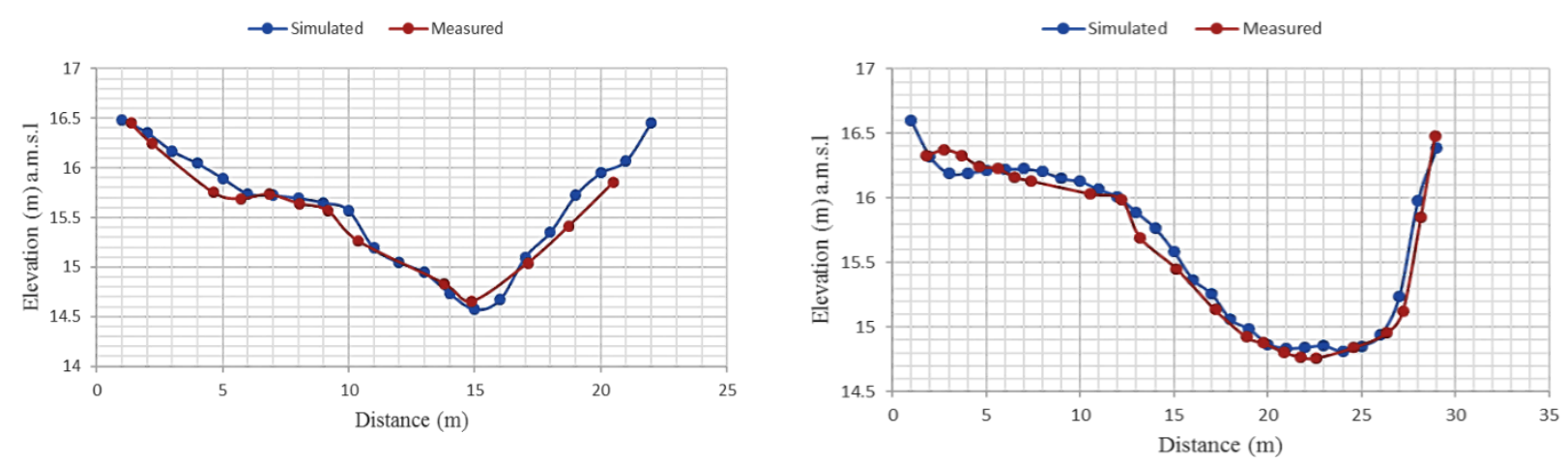

\subsection{Scenarios for Controlling Erosion and Deposition Zones at the Kurau and Ara Rivers Confluence}

Many types of obstacles were used in the riverine system to manage and control the training of the rivers. Spurdykes, vanes, groynes, and weirs are among the obstacles used by U.S. Army Corps of Engineers, USACE [32]. In this study, vanes are used as obstacles to assess the hydro-morpho-dynamics of natural rivers at confluence. This type of structure is introduced in the model by creating a polygon which is excluded throughout mesh computing and considered 
by the model as an obstacle [36]. The impact of the obstacle on the flow in rivers conjunctions is clearly shown on the computation of riverbed variation, and velocity distribution with the development, appearance and movement of the sandbar. Simulated of the confluence bathymetry with and without obstacle after the third day of the model run with discharge of $43 \mathrm{~m}^{3} / \mathrm{s}$ were analyzed, owing to the great effect that it will make on the hydro-morpho-dynamics which recognized at the confluence zone and marked the change in the flow depth, scouring zone, deposition zone, and velocities with its vectors for the following three scenarios:

a) A single row of the obstacles/vanes with $1 \mathrm{~m}$ long and a spacing of $6 \mathrm{~m}$ between them at angle of nearly $\left(30^{\circ}\right)$ with the flow direction of Ara river.

b) A single row of the obstacles/vanes with $2 \mathrm{~m}$ long and a spacing of $5 \mathrm{~m}$ between them at angle of nearly $\left(30^{\circ}\right)$ with the flow direction of Ara river.

c) A single obstacle/vane with $10 \mathrm{~m}$ long at angle of nearly $\left(30^{\circ}\right)$ with the flow direction of Ara river.

\subsubsection{First scenario: A single row of the obstacles/vanes with 1-m-long}

Due to the maximum scour at this area which is caused by high flow from Ara river, a single row of vanes with $1 \mathrm{~m}$ long were placed at the junction near the Ara river mouth. The length of a vane is calculated based on water depth, which is equal 0.3 of the flow depth [45]. The spacing between them is obtained by calculation and found to be 2 multiplied by the flow depth. This was recommended by previous studies [46, 47]. In addition, the optimum angle of the obstacle was taken as $30^{\circ}$ as recommended by Odgaard and Spoljaric, [48], Barkdoll et al., [49] and Wuppukondur and Chandra, [45]. They reported that the scour depth is increased with an increase in vane angle and this is the reason why the obstacles/vanes installed with an angle of $30^{\circ}$, also in this case increasing obstacles/vanes angle will allow to pass more inflow discharge from Ara river toward outer bank of main Kurau river and lead to enhance the scouring zone. The model was run using real data of unsteady flow as shown in Table 2. For a discharge of $43 \mathrm{~m}^{3} / \mathrm{s}$, model output with and without obstacles/vanes were compared. Figs. 26 and 27 show the comparison of water depth and velocity distribution with its vectors respectively. Introducing obstacles/vanes the simulated results show that there is not much change in the maximum scour hole near the outer bank and deposition zone near the inner bank at the confluence. The velocity magnitude at the deposition zone was increased a little bit and reached to $0.53 \mathrm{~m} / \mathrm{s}$, in which this value does not exceed the mean critical velocity of sediment transport at this zone. The mean critical velocity was calculated based on Simons and Şentürk method [50] and found to be $0.56 \mathrm{~m} / \mathrm{s}$. However, the results of imposing obstacles/vanes in this scenario will not bring significant improvement to the hydro-morpho-dynamics of the confluence. Therefore, the length of the obstacles/vanes was doubled, and the results are shown in the second scenario.

\subsubsection{Seconded scenario: A single row of the obstacles/vanes with 2-m-long}

In Seconded scenario, the simulation included using a single row of inclined obstacles/vanes with $2 \mathrm{~m}$ long and spacing of $5 \mathrm{~m}$. The angle of inclination of obstacles/vanes was taken as $30^{\circ}$ from the flow direction of Ara river. The simulation results on the flow depth, velocity magnitude and vectors of velocity were demonstrated in Figures 26 (c) and 27 (c). Good results are presented by doubled the length of the obstacles/vanes especially on reducing the maximum area of the scour hole, but on the deposition zone there is not great change compared with simulation without obstacles/vanes.

\subsubsection{Third scenario: A single obstacle/vane with 10-m-long}

In this scenario, a single vane with $10 \mathrm{~m}$ long is placed at an angle of $30^{\circ}$ and the same location of the vanes used in first and second scenarios. The simulated flow depth and velocity distribution with its vectors are shown in Figures 26 (d) and 27 (d) respectively. This scenario gave the best results since the deposition zone was maintained, while the zone with maximum scour hole was diminished. This is because the flow direction was changed toward the zone of low pressure and velocity (deposition zone) and maintained the potential of sediment movement and deposition. Figure 27 (d) show that by using the obstacle/vane of $10 \mathrm{~m}$ long, the maximum velocity is shifted away from the outer bank toward the centerline of the confluence. However, imposing a single obstacle/vane give the best solution for maintaining hydromorpho dynamics and also enhance the navigation at the confluence of Kurau and Ara rivers.

\section{Conclusions}

The control of flow in rivers confluences is complex owing to different hydro-morpho-dynamics features that arise in this turbulence zone. A 2D numerical model has been used to simulate the hydro-morpho-dynamics of natural confluence taking the confluence of Kurau and Ara rivers, Perak, Malaysia as a case study. The numerical model has been calibrated and validated using field data. Obstacles/vanes have been suggested as a control structure to mitigate the scour and deposition zones that usually occur at the natural confluences. Also, the Mflow_02 model has been used to evaluate the morphological changes for three scenarios of obstacles/vanes arrangements. The simulation results show that by using a single $30^{\circ}$ obstacle/vane, a good performance obtained for controlling erosion and deposition zones compared with using raw of $30^{\circ}$ obstacles/vanes. There might be other solutions for training the flow at the rivers confluence with different dimension and angle. In summary, this paper addressed the applicability of using the 2D 
numerical model in a complex riverine system for predicting hydro-morpho-dynamics changes with and without obstacle as training structures in a dynamic river confluence.

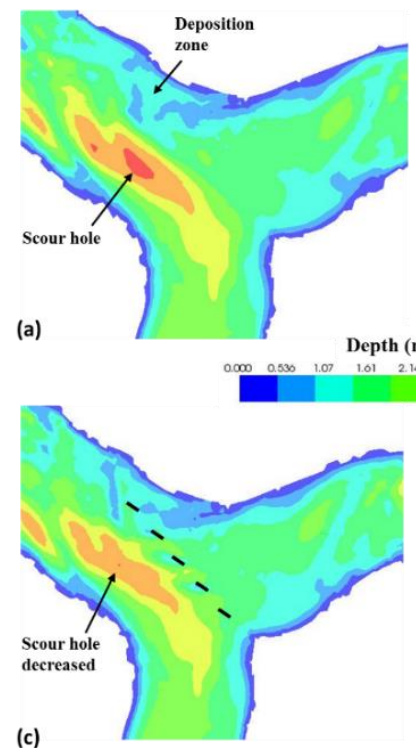

Fig. 26 - Simulated flow depth without and with obstacles/vanes for the study site (a) without obstacle; (b) First scenario; (c) Second scenario; (d) Third scenario

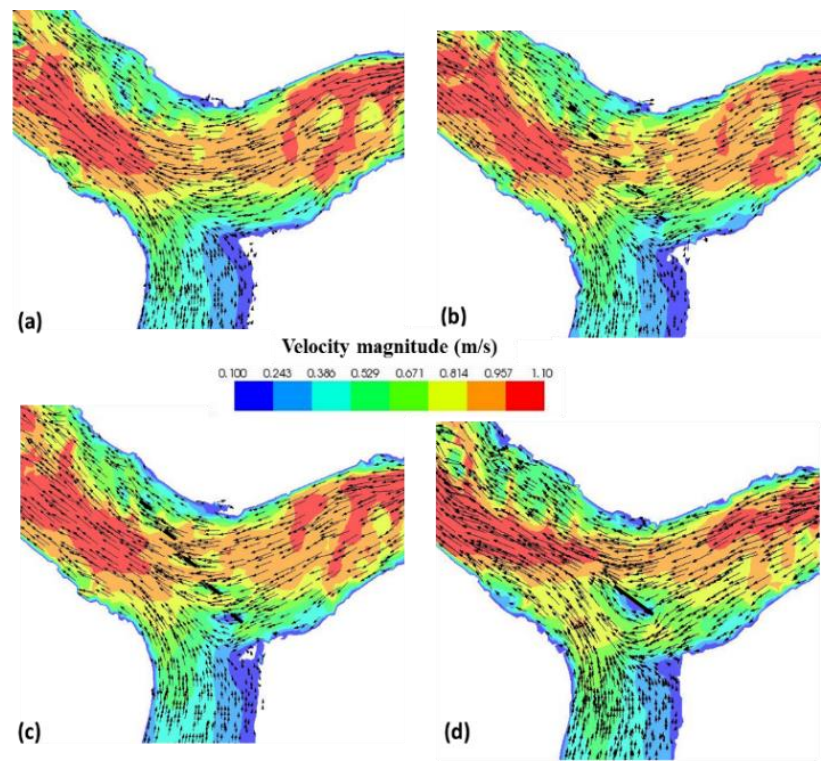

Fig. 27 - Simulated velocity distribution with its vectors without and with obstacles/vanes for the study site (a) without obstacle; (b) First scenario; (c) Second scenario; (d) Third scenario

\section{References}

[1] Riley J. D., Rhoads B. L., Parsons D. R. and Johnson K. K. (2014) Influence of junction angle on three-dimensional flow structure and bed morphology at confluent meander bends during different hydrological conditions, Earth Surf. Process. Landforms, 40, pages 252-271, doi: 10.1002/esp.3624.

[2] Ashmore, P., \& Parker, G. (1983). Confluence scour in coarse braided streams. Water Resources Research, 19(2), 392-402. https://doi.org/10.1029/WR019i002p00392.

[3] Guillén-Ludeña, S., Franca, M. J., Cardoso, A. H., \& Schleiss, A. J. (2016). Evolution of the hydromorphodynamics of mountain river confluences for varying discharge ratios and junction angles. Geomorphology, 255, 1-15. https://doi.org/10.1016/j.geomorph.2015.12.006

[4] Rhoads B. L. (1996). Mean structure of transport-effective flows at an asymmetrical confluence when the main stream is dominant. In P. J. Ashworth, J. S. J. Bennett, L. Best, \& \& S. J. McLelland (Eds.), Coherent Flow Structures in Open Channels (pp. 491-517). Chichester, UK: Wiley

[5] Rice, S. P., Roy, A. G., \& Rhoads, B. L. (2008). River Confluences, Tributaries and the Fluvial Network. River Confluences, Tributaries and the Fluvial Network. https://doi.org/10.1002/9780470760383

[6] Best, J. L. (1986). The Morphology of River Channel Confluences. Progress in Physical Geography, 10, $157-174$.

[7] Best, J. L. (1987). Flow Dynamics At River Channel Confluences: Implications for Sediment Transport and Bed Morphology. Recent Developments in Fluvial Sedimentology, (pp. 27-35). SEPM (Society for Sedimentary Geology). https://doi.org/10.2110/pec.87.39.0027

[8] Best, J. L. (1988). Sediment transport and bed morphology at river channel confluences. Sedimentology, 35, 481498. https://doi.org/10.1111/j.1365-3091.1988.tb00999.x

[9] Best, \& Reid. (1984). Separation Zone At Open-Channel Junctions. Journal of Hydraulic Engineering, 110(10), 1588-1594. https://doi.org/10.1061/(ASCE)0733-9429(1984)110:11(1588).

[10]Biron, P., Best, J. L., \& Roy, A. G. (1996). Effects of Bed Discordance on Flow Dynamics at Open Channel Confluences. Journal of Hydraulic Engineering, 122(12), 676-682. https://doi.org/10.1061/(ASCE)07339429(1996)122:12(676)

[11] Liu, T., Fan, B., \& Lu, J. (2015). Sediment - flow interactions at channel confluences: A flume study. Advances in Mechanical Engineering, 7(6), 1-9. https://doi.org/10.1177/1687814015590525

[12] Mosley, M. (1976). An experimental study of channel confluences. The Journal of Geology. Retrieved from http://www.jstor.org/stable/30066212 
[13] Yuan, S., Tang, H., Xiao, Y., Qiu, X., Zhang, H., \& Yu, D. (2016). Turbulent flow structure at a 90-degree open channel confluence: Accounting for the distortion of the shear layer. Journal of Hydro-Environment Research, 12, 130-147. https://doi.org/10.1016/j.jher.2016.05.006

[14] Ashmore, P. E., Ferguson, R. I., Prestegaard, K. L., Ashworth, P. J. and Paola, C. (1992), Secondary flow in anabranch confluences of a braided, gravel-bed stream. Earth Surf. Process. Landforms, 17: $299-311$. doi:10.1002/esp.3290170308

[15] Boyer, C., Roy, A. G., \& Best, J. L. (2006). Dynamics of a river channel confluence with discordant beds: Flow turbulence, bed load sediment transport, and bed morphology. Journal of Geophysical Research: Earth Surface, 111(4), 1-22. https://doi.org/10.1029/2005JF000458

[16] Parsons, D. R., Best, J. L., Lane, S. N., Kostaschuk, R. A., Hardy, R. J., \& Orfeo, O. (2008). River Confluences, Tributaries and the Fluvial Network - Google Books. In R. SP, R. AG, \& R. BL (Eds.), Large river channel confluences (pp. 73-91). John Wiley \& Sons: Chichester. https://doi.org/10.1002/9780470760383

[17] Rhoads, B. L., Riley, J. D., \& Mayer, D. R. (2009). Geomorphology Response of bed morphology and bed material texture to hydrological conditions at an asymmetrical stream confluence. Geomorphology, 109(3-4), 161-173. https://doi.org/10.1016/j.geomorph.2009.02.029

[18] Rhoads, B. L., and A. N. Sukhodolov (2008), Lateral momentum flux and the spatial evolution of flow within a confluence mixing interface, Water Resour. Res., 44, W08440, doi:10.1029/2007WR006634.

[19] Rhoads, B. L., \& Sukhodolov, N. (2001). Field investigation of three-dimensional flow structure. Water Resources Research, 37(9), 2393-2410. https://doi.org/10.1029/2001WR000316

[20] Roy, A. G., Roy, R., \& Bergeron, N. (1988). Hydraulic geometry and changes in flow velocity at a river confluence with coarse bed material. Earth Surface Processes and Landfomrs, 13, 583-598. https://doi.org/10.1002/esp.3290130704

[21] Szupiany, R. N., M. L. Amsler, D. R. Parsons, and J. L. Best (2009), Morphology, flow structure, and suspended bed sediment transport at two large braid-bar confluences, Water Resour. Res., 45, W05415, doi:10.1029/2008WR007428.

[22] Bradbrook, K. F., Biron, P. M., Lane, S. N., Richards, K. S., \& Roy, A. G. (1998). Investigation of controls on secondary circulation in a simple confluence geometry using a three dimensional numerical model. Hydrological Processes Hydrol. Process, 1396(November 1996), 1371-1396. https://doi.org/10.1002/(SICI)10991085(19980630)12:8<1371::AID-HYP620>3.0.CO;2-C

[23] Bradbrook, K. F., S. N. Lane, and K. S. Richards (2000), Numerical simulation of three-dimensional, time-averaged flow structure at river channel confluences, Water Resour. Res., 36(9), 2731-2746, doi:10.1029/2000WR900011.

[24] Schindfessel, L., Creëlle, S., \& De Mulder, T. (2015). Flow patterns in an open channel confluence with increasingly dominant tributary inflow. Water (Switzerland), 7(9), 4724-4751. https://doi.org/10.3390/w7094724

[25] Shakibainia, A., Reza, M., Tabatabai, M., \& Zarrati, A. R. (2010). Three-dimensional numerical study of flow structure in channel confluences. Canadian Journal of Civil Engineering, 37(5), $772-781$. https://doi.org/10.1139/L10-016

[26] Song, C. G., Seo, I. W., \& Kim, Y. Do. (2012). Analysis of secondary current effect in the modeling of shallow flow in open channels. Advances in Water Resources, 41, 29-48. https://doi.org/10.1016/j.advwatres.2012.02.003

[27] Ashmore, P., \& Gardner, and J. T. (2008). Unconfined Confluences in Braided Rivers. In S. P. Rice, B. Rhoads, L., \& R. A. G. (Eds.), River Confluences, Tributaries and the Fluvial Network. Chichester: John Wiley and Sons.

[28] Leite Ribeiro, M., Blanckaert, K., Roy, A. G., \& Schleiss, A. J. (2012). Flow and sediment dynamics in channel confluences. Journal of Geophysical Research: Earth Surface, 117(1). https://doi.org/10.1029/2011JF002171

[29] Birjukova, O., Guillen, S., Alegria, F., \& Cardoso, A. (2014). Three dimensional flow field at confluent fixed-bed open channels. Proc. River Flow. Retrieved from http://infoscience.epfl.ch/record/202026/files/2014-989

[30] Tannehill, J. C., Anderson, D. A., and Pletcher, R. H. (1997). Computational fluid mechanics and heat transfer, 2nd Ed., Taylor \& Francis Publisher, Philadelphia

[31] Karmaker, T., \& Dutta, S. (2016). Prediction of short-term morphological change in large braided river using 2D numerical model. Journal of Hydraulic Engineering, 142(10), 04016039.

[32] USACE (U.S. Army Corps of Engineers), (2012). Upper Mississippi river restoration environmental management program, environmental design handbook.

[33] Bhuiyan, F., Hey, R. D., \& Wormleaton, P. R. (2010). Bank-attached vanes for bank erosion control and restoration of river meanders. Journal of Hydraulic Engineering, 136(9), 583-596.

[34] DID (2009) Department of irrigation and drainage Malaysia. Study on river sand mining capacity in Malaysia.

[35] Sirdari, Z. Z., (2013). Bedload Transport for Small Rivers in Malaysia, (May). Retrieved from https://www.academia.edu/4147500/Bed_Load_Transport_of_Small_Rivers_in_Malaysia

[36]iRIC,(2014). Mflow_02 Solver Manual. Produced by Mineyuki Gamou, Released July 10, 2014, at http://iric.org/en/software/?c=19.

[37] Ashida, K., and Michiue, M. (1972). "Study on hydraulic resistance and bedload transport rate in alluvial streams," in Transcripts of the Japan Society for Civil Engineers, pp. 59-69. 
[38] Meyer-Peter, E., and Müller, R. (1948) Formulas for bed-load transport. Proceedings of the 2nd Meeting of the International Association for Hydraulic Structures Research, Stockholm, Sweden, 2(2), 39-64.

[39] Engelund, F. (1974). Flow and bed topography in channel bends. Journal of the Hydraulics Division, 100(Proc. Paper 10963).

[40] Teo, F. Y., Noh, M. N. M., Ghani, A. A., \& Zakaria, N. A. (2017). River Sand Mining Capacity In Malaysia. Proceedings of the 37th IAHR World Congress, August 13 - 18, 2017, Kuala Lumpur, Malaysia, 538-546.

[41] Papanicolaou, A. N., Elhakeem, M., Dermisis, D., and Young, N. (2011). "Evaluation of the Missouri River shallow water habitat using a 2D-hydrodynamic model." River Res. Appl., 27(2), 157-167.

[42] Pinto, L., Fortunato, A., and Freire, P. (2006). "Sensitivity analysis of non-cohesive sediment transport formulae." Cont. Shelf Res., 26(15), 1826-1839.

[43] Papanicolaou, A. N., Elhakeem, M., andWardman, B. (2010). "Calibration and verification of a 2D-hydrodynamic model for simulating flow around bendway weir structures.” J. Hydr. Eng., 10.1061/(ASCE)HY.19437900.0000280, 75-89.

[44] Papanicolaou, A. T. N., Elhakeem, M., Krallis, G., Prakash, S., \& Edinger, J. (2008). Sediment transport modeling review-current and future developments. Journal of Hydraulic Engineering, 134(1), 1-14.

[45] Wuppukondur, A., \& Chandra, V. (2017). Methods to control bed erosion at $90^{\circ}$ river confluence: an experimental study. International Journal of River Basin Management, 15(3), 297-307.

[46] Odgaard, A. J., \& Wang, Y. (1991). Sediment management with submerged vanes. I: Theory. Journal of Hydraulic Engineering, 117(3), 267-267

[47] Allahyonesi, H., Omid, M. H., \& Haghiabi, A. H. (2008). A study of the effects of the longitudinal arrangement sediment behavior near intake structures. Journal of Hydraulic Research, 46(6), 814-819

[48] Odgaard, A. J., \& Spoljaric, A. (1986). Sediment control by submerged vanes. Journal of Hydraulic Engineering, 112(12), 1164-1180

[49] Barkdoll, B. D., Ettema, R., \& Odgaard, A. J. (1999). Sediment control at lateral diversions: Limits and enhancements to vane use. Journal of Hydraulic Engineering, 125(8), 862-870.

[50] Simons, D. B., \& Şentürk, F. (1992). Sediment transport technology: water and sediment dynamics. Water Resources Publication 